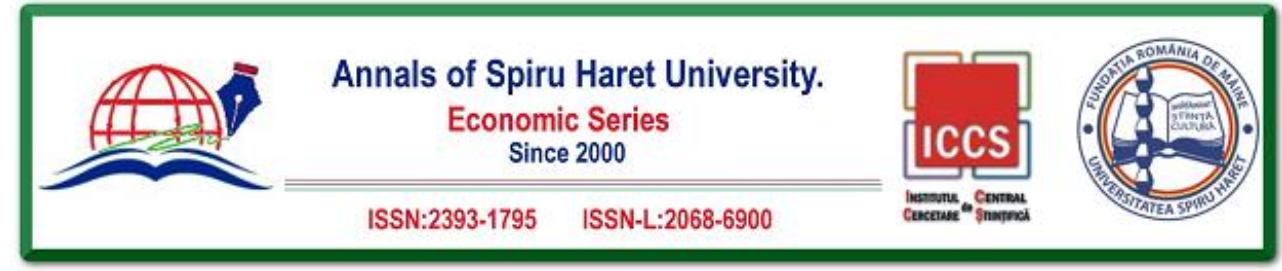

Issue 3/2018

\title{
WORKFORCE REGIONAL DISPARITIES FROM THE RURAL AREA IN ROMANIA
}

\author{
Mădălina Teodora ANDREI ${ }^{1}$, Iuliana POP ${ }^{2}$, Grațiela GHIC ${ }^{3}$ \\ ${ }^{1}$ Spiru Haret University, 13 Ion Ghica street, Bucharest, \\ Romania/National Agency for Natural Protected Areas, 151 Lacul Morii \\ street, Bucharest, Romania, Email: madalina.teodora.andrei@gmail.com \\ ${ }^{2}$ University of Economic Studies, 6 Piata Romana, Bucharest, Romania, \\ Email: iuliana.pop@rei.ase.ro \\ 3 “Dimitrie Cantemir" Christian University, 176 Splaiul Unirii Street, \\ Bucharest, Romania, Email: grati.ela@alternativeit.ro
}

How to cite: ANDREI, M. A., POP, I. \& GHIC, G. (2018). "Workforce Regional Disparities from the Rural Area in Romania." Annals of Spiru Haret University. Economic Series, 18(3), 59-68, doi: https://doi.org/10.26458/1834

\section{Abstract}

The beginning of the third millennium has brought up in Romania significant changes as far as the demographic and economic phenomena in general, and the workforce from the rural area in particular. The demographic evolution in Romania is influenced by multiple factors, including economic, social and political ones.

This article aims at performing a quantitative analysis on the employment level and development trends of Romania's rural area population at the regional level with a view of becoming competitive at the European level.

Keywords: workforce; rural population; development region; labour force; employed; competitiveness.

JEL Classification: $\mathrm{J}_{1}, \mathrm{~J}_{2}, \mathrm{~J}_{6}, \mathrm{Q}_{1}, \mathrm{R}_{2}$

\section{Introduction}

Demographic analysis at the national or regional levels is of a particular importance, as the growth of the population or its reduction has repercussions on the workforce potential. In its turn, the latter has huge implications on the economic 




Issue $3 / 2018$

activities of the European Union (EU) Member States both at the national and EU levels.

Romania's population has recorded a significant decrease at the beginning of the third millennium, particularly in rural areas.

If until 1989 there was a migration push towards the city, after the December 1989 Romanian Revolution there was a comeback in rural areas triggered by the process of putting in possession of former nationalized properties or by the attractiveness of a more natural and peaceful living environment.

The systemic changes produced in rural areas after 1989 as far as propriety, activity sectors and workforce are concerned, have led to a significant mobility of the labour force, both towards cities and other foreign countries, particularly from the EU.

Romania's accession into EU in 2007 has opened new gateways for the Romanian labour force to access the European labour market.

From a geographic perspective, the labour force represents the population able to work, has theoretical and practical knowledge and skills which support its professional competence and integration capacity in the socio-economic activity [Erdeli et al., 1999].

From an economic perspective, the labour force represents the physical and intellectual potential of the people through which they produce material goods and useful services; it encompasses a quantitative element - the whole population able to work - and a qualitative one - the level of education and the skills of those able to work [Dobrotă et al., 1999].

Among the factors which explain why the workforce is unevenly distributed nationally one could cite the density of the population which presents differentiation from region to region according to the particularities of physical geography and economic geography, and the attractiveness of urban areas.

The analysis of the main demographic indicators offer also a relevant image of the socio-economic development level of a region, indicating at the same time their attractiveness level, both from to viewpoints of habitat and economic development perspectives.

The demographic indicators refer to the number and percentage of the rural population and their dynamics, bringing also information on the demographic dependence, demographic ageing and natural and migratory movements of the population.

In view of obtaining an objective picture of the workforce distribution, we have researched it at the regional level.

60 


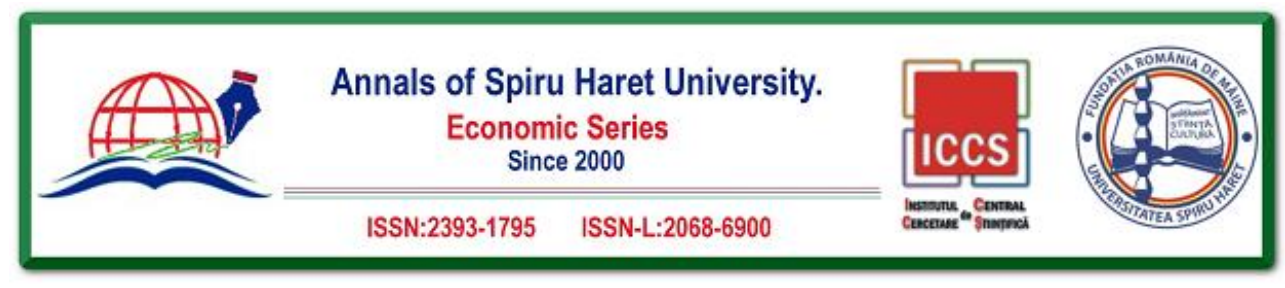

Issue 3/2018

Although after 1989 Romania there was an attempt at reinstating the counties from the interwar period, this was not implemented, as the general European tendency was that of putting in place powerful administrative units, enjoying a large local autonomy. At present, Romania has 42 counties (including Bucharest municipality) and according to the Law for regional development of Romania from 1998, have been set up eight development regions, having no legal personality [Negut, 2011]. They correspond to the NUTS II statistical level. These regions are characterized by a relative uniformity of their size and demographic potential, which confers viability to statistical data.

The labour force at the level of development regions presents an objective picture of a nation-wide reality. It should be dealt with according to the needs of each region and the medium- and long-term solutions for preserving the cultural, social and economic values of the Romanian rural environment.

\section{Literature Review}

The Romanian village has been the object of study for both geographers and sociologists. Among the Romanian geographers who devoted a particular attention to the study of rural geography one could cite V. Cucu (2000). He focused on the characteristics of human communities in rural areas in tight connection with the functional effects of the latter on the organizational forms. Geographical works related to population have been written also by Erdeli and Dumitrache (2001, 2009). They present new demographic approaches which led to new fields of study such as social demography, political demography or statistical demography.

A geographic approach on population and workforce one can find also in the work of Ungureanu, et al. (2002).

A sociological study which presents theoretical aspects of rural societies and the main social problems which confronts the Romanian village was performed by Bădescu, et al. (2011).

Several works on the workforce training in the rural areas from the Timiş County were written by Palicia and Palicia (2005).

Mihalache (2013) analyzes the level of employment and economic activities in rural areas, as well as Şerban and Juravle (2012) that focus on the level of employment and the quality of human resources in the Romanian rural environment.

Tudose (2005) tackled the occupational structure of the population from the Centre development region, focusing on the labour force and its perspectives. 


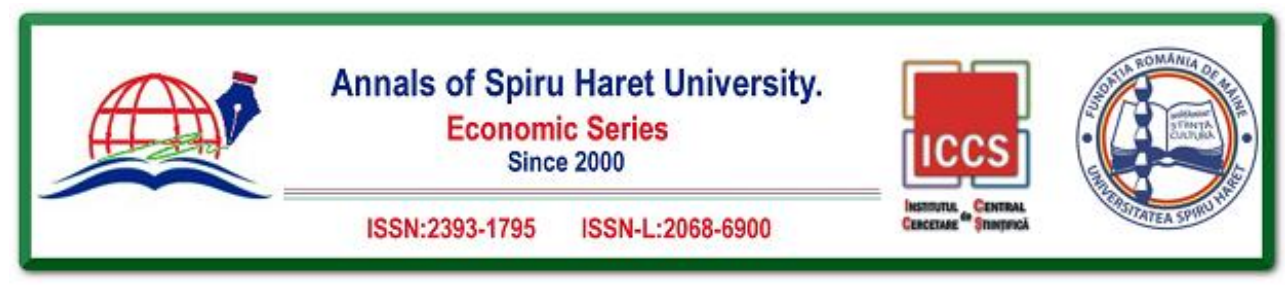

Issue 3/2018

\section{Characteristics of the Rural Space in Romania}

The rural space has a special relevance for Romania, both in terms of size and function. The Romanian rural space represents 87.1 percent of Romania's area [MADR, 2013], and in this area live 9,124,490 inhabitants (as of the $1^{\text {st }}$ of January 2016), representing 46.2 percent of Romania's population [România în cifre, 2017].

Against the background of negative natural increase and international migration balance, the rural area population has decreased in the last years. In comparison with 2013, in 2016 the rural population has diminished with 91,526 inhabitants [România in cifre, 2016]. By analyzing the permanent resident population by residence area, we notice that out of 22,214,995 inhabitants (as of the $1^{\text {st }}$ of January 2016) 9,700,696 live in rural areas, which is more than the usual resident population [România în cifre, 2017]. In comparison with the usual resident population which presents a decreasing trend, the permanent resident population is relatively stable.

In rural areas there are 2,861 communes in total (as of the $1^{\text {st }}$ of January 2016), the largest number of them, 1,669, having between 2,000 and 4,999 inhabitants [România în cifre, 2017].

The active population at the national level numbered 8,979,000 persons, out of which 4,017,000 in rural areas. Out of the whole active population at the national level were employed 8,449,000 persons, whereas in the rural areas were employed $3,765,000$ persons. One can notice that in rural areas the number of unemployed is less than in urban areas, namely 252,000 persons as compared with 278,000 persons, but also the active and employed population is less in rural areas [România în cifre, 2017].

Up till 2002, the majority of the employed population was in rural areas. Starting 2003, the biggest part of the employed population resides in urban areas [România în cifre, 2017].

Vital statistics point to a decrease of Romania's population caused by a negative natural increase. The size of the younger population (0-14 years) is decreasing, whereas the size of the elder population (beyond 60 years) is increasing.

These trends will lead to an ageing population and a diminished labour force. This phenomenon is not entirely characteristic to rural areas, but it affects also cities. However, the effects are more visible in small rural communities, which remained populated especially by elder and poor persons which cannot afford a decent living. More often than not, families have among their members elder persons or are composed entirely by such persons, as the younger members of the family have migrated towards urban areas or foreign countries where development 


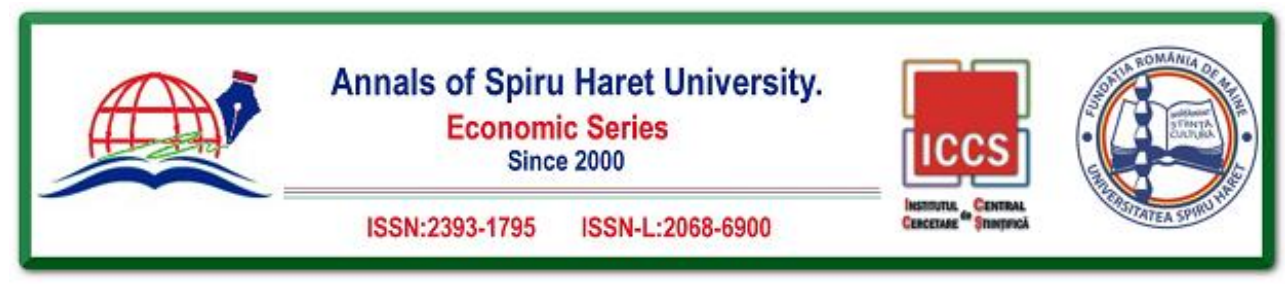

Issue 3/2018

opportunities secure them a higher standard of living. On the other hand, the traditional values related to family have decreased even in the Romanian villages as youngsters are motivated by carrier opportunities and living in cities.

\section{The Analysis of Workforce at the Development Region Level}

The territorial structure of Romania according to EUROSTAT's NUTS presents at the NUTS II level eight development regions in Romania. Within these development regions the rural population is not evenly distributed, as there are significant differentiations from the viewpoint of population's density. The majority of communes with less than 50 inhabitants $/ \mathrm{km}^{2}$ are in the Western part of the country, in comparison with the Eastern and Southern parts, where the values are higher, namely between 50 and 100 inhabitants $/ \mathrm{km}^{2}$, the average at the national level being 82.9 inhabitants $/ \mathrm{km}^{2}$ as of the $1^{\text {st }}$ of January 2016 [România în cifre, 2017].

The eight development regions are:

- The North-West region, with Bihor, Bistriţa-Năsăud, Cluj, Maramureş, Satu Mare and Sălaj counties;

- The Centre region, with Alba, Braşov, Covasna, Harghita, Mureş and Sibiu counties;

- The North-East region, with Bacău, Botoşani, Iaşi, Neamţ, Suceava and Vaslui counties;

- The South-East region, with Brăila, Buzău, Constanţa, Galaţi, Tulcea and Vrancea counties;

- The South-Muntenia region with Argeş, Călăraşi, Dâmboviţa, Giurgiu, Ialomiţa, Prahova and Teleorman counties;

- The Bucharest-Ilfov region, with Ilfov county and Bucharest municipality;

- The South-West Oltenia region, with Dolj, Gorj, Mehedinţi, Olt and Vâlcea counties;

- The West region, with Arad, Caraş-Severin, Hunedoara and Timiş counties.

Within these eight development regions, the most extended surface belongs to the North-East development region, with $36,849.83 \mathrm{~km}^{2}$, followed by the SouthEast development region; the smallest surface belongs to the Bucharest-Ilfov development region, with $1,821.15 \mathrm{~km}^{2}$. The differences among other development regions are not so high (Table 1). 




Issue $3 / 2018$

Table 1. Total Area and Utilized Agricultural Area by Development Regions in Romania

\begin{tabular}{|l|l|r|}
\hline Development regions & Total area $\left(\mathrm{km}^{2}\right)$ & Utilized agricultural areas (ha) \\
\hline North-West & $34,160.46$ & $1,783,215.05$ \\
\hline Centre & $34,099.72$ & $1,512,475.52$ \\
\hline North-East & $36,849.83$ & $1,909,253.52$ \\
\hline South-East & $35,761.70$ & $2,064,806.28$ \\
\hline South Muntenia & $34,452.99$ & $2,114,708.76$ \\
\hline Bucharest-Ilfov & $1,821.15$ & $64,277.05$ \\
\hline South-West Oltenia & $29,211.69$ & $1,479,930.68$ \\
\hline West & $32,033.17$ & $1,573,868.63$ \\
\hline
\end{tabular}

Source: Ancheta structurală în agricultură 2016, volume 2. Bucureşti: Institutul Naţional de Statistică, 2017

As far as the rural population in the development regions is concerned, the highest number is registered in the North-East development region, with 3,924,954 inhabitants, followed by the South-Muntenia development region with 3,249,927 inhabitants. These large and populous development regions encompass lower altitude areas, which present favourable conditions of living (Table 2).

By no chance, these regions have also a large agricultural surface. The most extended agricultural surface within the eight development regions encompasses the southern and eastern parts of Romania, i.e. the South-Muntenia development region, with 2,114,708.76 ha, and the South-East development region, with $2,064,806.28$ ha, whereas the North-East accounts for more than half of the total surface of the region, 1,909,253.52 ha (Table 1).

These regions cover mostly plain areas (the bulk of Romanian's Plain and Moldova's Plain), but also hilly areas propitious to agricultural activities [INS, 2017].

The South-Muntenia development region confronts itself with an advanced ageing process. In order to analyze the phenomenon of population ageing has been used the demographic ageing index, which represents the number of elder persons 65 (years and beyond) to 100 young persons (under 15 years) [Populaţia României după domiciliu, 2016]. At the region level the ageing index is 123 , whereas in the rural area is even 
higher, namely 132.7. With respect to gender, the female population has a 167 ageing index, in comparison with the male rural population, with a 100.5 ageing index.

Table 2. Total Population by Development Region, Sex and Area, on July 1, 2016

\begin{tabular}{|l|r|r|r|r|}
\hline \multirow{2}{*}{$\begin{array}{c}\text { Development } \\
\text { regions }\end{array}$} & \multirow{2}{*}{$\begin{array}{c}\text { Total population } \\
\text { by development } \\
\text { region }\end{array}$} & \multicolumn{3}{|c|}{ Rural population by development region } \\
\cline { 3 - 5 } & $2,832,637$ & $1,296,608$ & 648,269 & 648,339 \\
\hline North-West & $2,632,384$ & $1,055,031$ & 531,462 & 523,569 \\
\hline Centre & $3,924,954$ & $2,159,657$ & $1,098,295$ & $1,061,362$ \\
\hline North-East & $2,863,758$ & $1,270,171$ & 639,273 & 630,898 \\
\hline South-East & $3,249,927$ & $1,858,212$ & 922,957 & 935,255 \\
\hline South Muntenia & $2,500,729$ & 220,087 & 107,605 & 112,482 \\
\hline Bucharest-Ilfov & $2,198,718$ & $1,104,974$ & 553,283 & 551,691 \\
\hline $\begin{array}{l}\text { South-West } \\
\text { Oltenia }\end{array}$ & $2,011,888$ & 735,956 & 366,266 & 369,690 \\
\hline West & & & & \\
\hline
\end{tabular}

Source: Populaţia României pe localităţi. Bucureşti: Institutul Naţional de Statistică, 2016

Table 3. Demographic Ageing Index by Development Region, Sex and Rural Area

\begin{tabular}{|c|c|c|c|c|}
\hline \multirow[t]{2}{*}{ Development regions } & \multirow{2}{*}{$\begin{array}{l}\text { Demographic } \\
\text { ageing index by } \\
\text { development } \\
\text { regions }\end{array}$} & \multicolumn{3}{|c|}{$\begin{array}{l}\text { Demographic ageing index by total rural } \\
\text { population and sex by development regions }\end{array}$} \\
\hline & & Total & Male & Female \\
\hline North-West & 100.3 & 135.2 & 80 & 127 \\
\hline Centre & 100.5 & 90.7 & 72.4 & 110 \\
\hline North-East & 87.6 & 89.4 & 70.1 & 109.6 \\
\hline South-East & 110 & 110.7 & 86.2 & 136.5 \\
\hline South Muntenia & 123 & 132.7 & 100.5 & 167 \\
\hline Bucharest-Ilfov & 113.8 & 87.1 & 66 & 109.6 \\
\hline South-West Oltenia & 128.7 & 158 & 122 & 196 \\
\hline West & 117.8 & 118.5 & 93.2 & 145.3 \\
\hline
\end{tabular}

Source: Statistical data processed by authors by Populația României pe localităţi. Bucureşti: Institutul Naţional de Statistică, 2016 


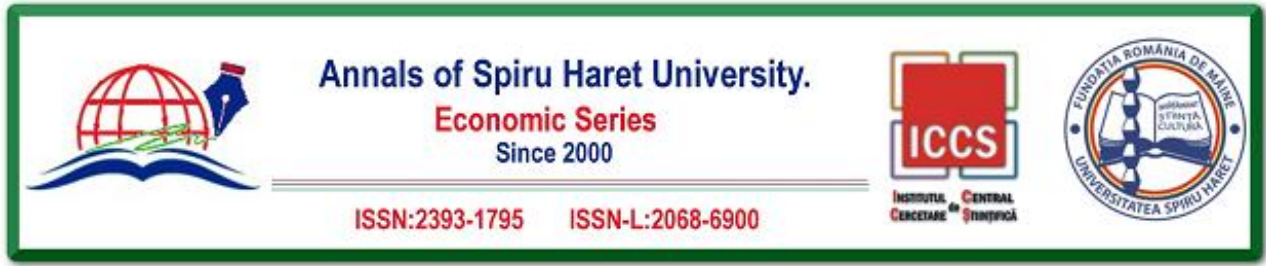

\section{Issue $3 / 2018$}

The most affected development region as far as the ageing index is concerned is the South-West Oltenia, where at the level of the region the value is 128.7, whereas in the rural areas, the ageing index is the highest, namely 158; in rural areas the ageing index of female population scores much higher, i.e. 196, in comparison with the male population, i.e. 122 (Table 3 ).

The demographic ageing index is correlating with the demographic dependency index, which refers to the ratio between the population defined as dependent (under 15 years and 65 years and beyond) and the population able to work (between 15 and 64 years) accounted for at 100 persons. Thus, one can notice that those development regions with an ageing population have also a higher ratio of demographic dependency, namely 46.3 for South-Muntenia development region, and for the rural regions even a higher one of 53.5 (Table 4).

Table 4. Demographic Dependency Index by Development Regions and Area

\begin{tabular}{|l|c|c|}
\hline Development regions & $\begin{array}{c}\text { Dependency index by } \\
\text { development region }\end{array}$ & $\begin{array}{c}\text { Dependency index by } \\
\text { rural area by } \\
\text { development region }\end{array}$ \\
\hline North-West & 43.6 & 50.3 \\
\hline Centre & 44.4 & 50.2 \\
\hline North-East & 44.6 & 50.8 \\
\hline South-East & 43.3 & 50 \\
\hline South Muntenia & 46.3 & 52.2 \\
\hline Bucharest-Ilfov & 42 & 44.2 \\
\hline South-West Oltenia & 44.2 & 53.5 \\
\hline West & 42 & 46.7 \\
\hline
\end{tabular}

Source: Statistical data processed by authors by Populaţia României pe localităţi. Bucureşti: Institutul Naţional de Statistică, 2016

In rural areas all development regions present higher values for these indexes as compared to those at the region level, and those regions with a higher percentage of rural population are heavily impacted by the above-mentioned situation.

\section{Conclusions}

The human resources represent a very important factor for each and every country, along with infrastructure and natural, technological and financial 




Issue 3/2018

resources. They provide the necessary workforce for economic development, at the same time being an important factor of competitiveness at the national level.

For a long time, the low-cost of labour in the rural areas of Romania represented an important source of competitive advantage. At present, the low-cost workforce does not represent anymore a competitive advantage for Romania. Therefore, the quality of training and acquiring new skills by the labour force are important factors for competitiveness.

A higher competitiveness implies building economic structures based on investments and research, development and innovation processes.

From the development viewpoint, rural areas are characterized by persistent structural deficiencies, such as: a high number of persons employed in agriculture; an ageing population process; a high number of subsistence holdings; a low added value of agricultural food products; a poor entrepreneurial spirit for developing economic activities; reduced access to credits; growing regional disparities; a high percentage of population exposed to poverty; and social exclusion.

Another important aspect for the labour force in rural areas is migration and its consequences. The elder migrants are substituting slowly the younger population in rural areas. The active rural population migrates towards urban areas in search of better workplaces and a more attractive living style.

International migration is also growing, involving especially the younger population who more often than not opt for temporary employment. Male migration seems to be higher than female migration. For the rural areas population which benefits from a rich natural and cultural rural environment, tourism represents an alternative to local economic activities. For tourists to become more interested in rural tourism, a diversification of the tourism offer is needed. Besides leisure, this could include training in rural crafts and agricultural practices, thus emphasizing the formative aspect of tourism. Within rural tourism, priority is to be given to agrotourism and eco-tourism.

The regional competitiveness and labour force employment was one of the prioritized objectives of the EU cohesion policy throughout 2007-2013. It was financed by the European Regional Development Fund (ERDF) and the European Social Fund (ESF).

In the current cycle between 2014 and 2020, the EU economic and social cohesion policy and the EU rural development policy have a common mission, namely to diversify the economic activities and to improve the quality of life in rural areas. 




Issue 3/2018

\section{References}

1. Bădescu, I., Cucu-Oancea, O., \& Şişeşteanu, G. Tratat de sociologie urbană. Bucureşti: Mica Valahie, 2011.

2. Cucu, V. Geografia aşezărilor rurale. Târgovişte: Domino, 2000.

3. Dobrotă, N. et al. Dicţionar de economie. Bucureşti: Economică, 1999.

4. Erdeli, G., \& Dumitrache, L. Geografia populaţiei mondiale. Bucureşti: Universitară, 2009.

5. Erdeli, G., \& Dumitrache, L. Geografia populaţiei. Bucureşti: Corint, 2001.

6. Erdeli, G. et al. Dicţionar de geografie umană. Bucureşti: Corint, 1999.

7. Mihalache, F. (2013). "Economic Activities in the Rural Area and Considerations about Population's Employment.” Revista Transilvană de Ştiinţe Administrative, 1 (32): 66-82.

8. Neguţ, S. Geografie umană. Bucureşti: Academiei Române, 2011.

9. Palicica, L. I., \& Palicica, M. Resursele umane şi pregătirea forţei de muncă din mediul rural. Timişoara: Orizonturi universitare, 2005.

10. Şerban, A., \& Juravle (Gasler), A. (2012). "The Romanian Rural Areas in the Context of European Development Strategies." Revista Română de Sociologie, serie nouă, year XXIII, 3-4, pp. 265-281.

11. Tudose, I. (2005). "Analiza structurii ocupaţionale a populaţiei din Regiunea de Dezvoltare Centru şi a perspectivelor acesteia." Analele Universităţii Creştine "Dimitrie Cantemir". Seria: Economie-Comerţ şi Turism, pp. 109-126.

12. Ungureanu, Al., Groza, O., \& Muntele, I. Moldova - populaţia, forţa de muncă şi aşezările umane în tranziţie, Iaşi: Corson, 2003.

13. Anuarul Statistic al României. Bucureşti: Institutul Naţional de Statistică, 2016.

14. Ancheta Structurală în Agricultură 2016, vol. 2. Bucureşti: Institutul Naţional de Statistică, 2017.

15. Populaţia României pe localităţi - după domiciliu. Bucureşti: Institutul Naţional de Statistică, 2016.

16. România în cifre - Breviar statistic 2017. Bucureşti: Institutul Naţional de Statistică, 2017.

17. Strategia de dezvoltare rurală a României 2014-2020. Bucureşti: Ministerul Agriculturii şi Dezvoltării Rurale, 2013. 